Miroseawa Michalska-Suchanek

Uniwersytet Śląski w Katowicach

\title{
"MIĘDZY SYNAGOGĄ I KOSMODROMEM BAJKONUR" O powieści Diny Rubiny Oto idzie Mesjasz!
}

Powieść Bom udem Meccuя! (Oto idzie Mesjasz!) Dina Rubina pisała w latach 1995-1996, tj. pięć lat po repatriacji z Rosji do Izraela. Książka ukazała się w 1996 roku jednocześnie w Moskwie (w miesięczniku „Дружба народов”, nr 9-10) i w Tel-Awiwie, gdzie uhonorowano ją nagrodą tamtejszego Związku Pisarzy. Narodowa powieść izraelska, jak ją nazywa Eleonora Szafrańska ${ }^{1}$, przedstawia rzeczywistość lat 90. w czasach masowej repatriacji obywateli byłego Związku Sowieckiego, która objęła około pół miliona Żydów i ich nie-żydowskich małżonków². Przybycie do kraju w krótkim czasie tak dużej liczby osób musiało zrodzić konflikt między repatriantami i społecznością Izraela, zwłaszcza sefardyjską, obawiającą się

${ }^{1}$ Э. Шафранская, Синдром голубки. Мибопоэтика прозы Дины Рубиной, Санкт-Петербург 2012, s. 13, http://www.academia.edu/28064407/Синдром_ голубки.pdf (3.01.2017).

${ }^{2}$ Portal Wirtualny Sztetl podaje, że w 1990 roku przybyło do Izraela 189,7 tys. emigrantów z krajów byłego Związku Sowieckiego; w sumie w latach 1989-1995 — 557,4 tys. Według izraelskiego Ministerstwa Absorpcji ok. 17\% z nich nie było Żydami, http://www.sztetl.org.pl/pl/term/404,emigracja-z-zsrr-do-izraela/ (20.02.2017). 
zepchnięcia jej na margines. Komplikowała się sytuacja społeczna i ekonomiczna, rosła konkurencja na rynku pracy, zwłaszcza w sektorze niewymagającym wykształcenia, gdzie zarobku poszukiwali rosyjscy Żydzi - w dużej części absolwenci wyższych uczelni, pracownicy dobrze wykwalifikowani, dla których nie było miejsc pracy w wyuczonym zawodzie, lub których kompetencje bez znajomości języka hebrajskiego okazywały się bezwartościowe. Repatrianci borykali się z trudnościami związanymi z procesem asymilacyjnym i nie zawsze życzliwym przyjęciem ze strony Izraelczyków, zamykając się we własnych (rosyjskich) enklawach ${ }^{3}$. Dopiero z upływem lat sytuacja zaczęła ulegać zmianie w kierunku identyfikacji z lokalną społecznością, stopniowo też malała potrzeba podkreślania własnej odmienności.

Powieść Oto idzie Mesjasz! zbudowana jest z dwóch odrębnych ciągów fabularnych, które zbiegają się w tragicznym finale. Halina Waszkielewicz podkreśla hybrydową harmonię powieściowej rzeczywistości, mozaikowość przedstawionych losów i panoramiczność obrazu4 4 Sama Rubina mówi natomiast o karnawalizacji świata przedstawionego, definiując to pojęcie jako mnogość obrazów, wielorakość postaci, masek i teatralność, a nawet farsowość pokazywanego życia ${ }^{5}$. Na nieprzewidywalną, niełatwą codzienność Izraela (przede wszystkim „rosyjskiego Izraela”) Rubina spogląda z perspektywy tradycji, kultury i religii żydowskiej, tworząc spójny obraz, nasycony w równym stopniu komizmem, ironią, a nawet groteską, co refleksją o charakterze filozoficzno-religijnym.

$\mathrm{W}$ powieści $\mathrm{z}$ mocą wybrzmiewają myśli o odwiecznym przeznaczeniu narodu żydowskiego i przekonanie o koherencji Żydów

${ }^{3}$ Zob. więcej: R. Tarasiuk, Aspiracje polityczne społeczności żydowskiej w Izraelu, s. 162-163, https://repozytorium.uph.edu.pl/bitstream/handle/11331/1135/ Tarasiuk.R_Aspiracje_polityczne_spolecznosci.pdf?sequence=1 (11.02.2017); E. Sidi, Izrael oswojony, Warszawa 2016, s. 218-220.

${ }^{4}$ H. Waszkielewicz, Hybrydowa harmonia. Dina Rubina „Oto idzie Mesjasz!”, w: J. Greń-Kulesza (red.), Literatury słowiańskie w kręgu tradycji kulturowych, Opole 2014, s. 139-140, 146.

${ }^{5}$ Zob. Д. Рубина, Под знаком карнавала, http://www.dinarubina.com/texts/ karnaval.html (10.01.2017). 
z własną ziemią. Nie w polityce, tylko w wyższym porządku świata tkwi geneza masowego wyjazdu rosyjskich Żydów do Izraela w latach 90., twierdzi autorka. Upadek sowieckiego imperium tylko ułatwił wypełnienie przeznaczenia. Fundamenty mocarstwa rozsypały się, aby zgodnie z Bożym planem Jego stado, po latach wygnania i tułaczki, powróciło na własne, dane mu od wieków, pastwisko. Żydzi przez dwa tysiąclecia rozproszeni byli po świecie i zewsząd ich wypędzano, jak bowiem o wybranym przez siebie narodzie powiada Żydowski Bóg: „[...] Я избрал тебя из всех народов, как стадо свое, и стану перегонять тебя, как стадо, с места на место, чтоб не забывал и не успокаивался, и не смешивался с языками другими...”6. Ale wreszcie nastał czas, aby „[...] пригнать Божье стадо на этот клочок извечного его пастбища, согласно не сегодня - ох, не сегодня! - составленному плану".

Powieść odbiera się jako manifestację przywiązania pisarki do własnego narodu, jego tradycji i przede wszystkim — nadanej Żydom przez Boga - ziemi. Stary Testament - przekonuje Rubina - wspaniale zachował się przez doświadczające Żydów tysiąclecia, lecz w ciągu ostatnich pięćdziesięciu lat „lśni jak nowy”, bo wzmacniany jest wiarą płynącą z żydowskiej ziemi i żydowskiego państwa: „[...] за последние лет пятьдесят так прямо засиял, как новенький, и подтверждает это на данном, нарезанном самим Всевышним дачном участке земли существование еврейского, вполне воззрелого государства $[\ldots] ”$.

Nie odnajdziemy w tej powieści tęsknoty za Rosją, goryczy utraty czy uczucia wyobcowania (być może zaledwie pięć lat po wyjeździe było jeszcze na to za wcześnie?). Bohaterowie, jak sama Rubina rosyjscy repatrianci, nie tęsknią za byłą ojczyzną, choć nieustannie powraca ona w rozmowach, jest punktem odniesienia, fundamentem doświadczeń i przedmiotem wspomnień. O kraju dzieciństwa i młodości mówią z sympatią, ale bez nostalgii, czas ten postrzegając jako jeden $z$ etapów życia. W świecie przedstawionym powieści bohaterowie Rubiny s ą j u ż I z r a e l c z y ka m i, którzy dźwigając swój - niewątpliwie nacechowany rosyjską przeszłością - bagaż

6 Tejże, Bom uдеm Месcuя!, http://loveread.ec/read_book.php?id=1933\&p=1 (1.01.2017). Stąd zaczerpnięte zostały wszystkie cytaty. 
doświadczeń, budują życie nie w now y m, lecz we wła s n y m kraju. Nie bez przyczyny Rubina konsekwentnie podkreśla swój status repatriantki, zdecydowanie odcinając się od określenia „emigrantka”, a Rosję i Izrael nazywa kolejnymi etapami własnego losu: „Невозможность побега от собственной судьбы. Так и живу [...]: Россия - судьба, Израиль - судьба"?.

Bohaterowie Rubiny żydowskość mają we krwi, w genach i w duszy. Tu, na tej ziemi jest ich miejsce i ich korzenie. Ziemia ta jest im przeznaczona i do niej należą. O Bori Kaganie narrator powiada:

Он ощутил вдруг с безвыходной ясностью, что и умерев и родившись вновь, даже при других обстоятельствах и в новой шкуре, он до страшного суда обречен чувствовать этот мир, судить о нем и совершать поступки, ведомый импульсами и предпочтениями своей древней еврейской души...

Na pytanie, czym różni się życie Żydów na ziemiach gojów od życia na własnej ziemi, Rubina odpowiada głosem jednego z bohaterów:

Тем, что твоя фамилия может прожить там тысячу лет, и полить кровью, и удобрить прахом своих поколений. Но все равно придет день, когда та земля крикнет тебе: „Грязный вонючий жид! Убирайся с моего тела!” Она будет орать тебе это в лицо, даже когда ты упадешь на нее на поле боя, она отравит тебе этим воплем последние минуты жизни, и ты умрешь с горечью в сердце, даже не зная - как читается „Шма Исраель” [...]. А твоя земля... Ты мог болтаться вдали от нее тысячу и две тысячи лет, но когда ты все таки вернешься сюда из прекрасного города своего детства и своей юности [...] она отверзает для тебя свое лоно и рожает тебе [...] А когда ты умираешь, она принимает тебя в последнее объятие и шепчет тебе слова кадиша - единственные слова, которые жаждет услышать твоя душа... Вот что такое эта земля — для тебя.

W przekonaniu Rubiny „ja” człowieka wyznaczają jego rodowe korzenie. W wywiadzie udzielonym Joannie Mianowskiej pisarka utożsamia ojczyznę z ziemią, którą nazwać można wła s n y m d o m e m. Jest to, okolony biografiami przodków i wyrosłych już

7 Tејże, Я и mы под персиковыми облаками, Москва 2008. Суt. za: H. Waszkielewicz, Hybrydowa harmonia..., s. 142. 
na tej ziemi własnych dzieci, proces mozolnego wieloletniego „wrastania" w nią, w jej problemy i dramaty, zaakceptowanie ludzi z nią związanych, i wreszcie jej samej ${ }^{8}$. W powstałej kilkanaście lat po Oto idzie Mesjasz! „trylogii powietrza” Rubina konstruuje coś na kształt kategorii rodu. Więź łącząca jednostkę z jej przodkami zyskuje tam status czynnika fundamentalnego, stanowiącego o jej życiu i tożsamości. Bohaterowie trylogii żyją w przestrzeni i czasie własnego rodu, które bezwarunkowo przyjmują za swoje ${ }^{10}$. Kategorię rodu w Oto idzie Mesjasz! realizuje motyw więzi Ziamy z własnym dziadkiem. Motyw ten Rubina „ogrywa” elementami tradycji żydowskiej, między innymi oburzeniem rodziny z powodu nadania dziewczynce imienia na cześć człowieka jeszcze żyjącego, albo faktem umycia przez dziadka nóg przed śmiercią, co - odczytane jako rytualne oczyszczenie - sprawiło, że w rodzinie z dumą powtarzano, iż zmarł on śmiercią męża sprawiedliwego. Ziama pielęgnuje pamięć o dziadku, a zacierający się obraz dopełnia opowieściami staruszek, przed laty w nim zakochanych, i wspomnieniem żydowskich powiedzeń, które niegdyś z upodobaniem powtarzał. Świadomość silnej więzi z dziadkiem-Żydem staje się dla bohaterki przypieczętowaniem jej narodowej tożsamości. To o niej narrator powiada:

Все было правильно: мозаичный узор судьбы подбирался по камушку, складывался медленно и старательно. И - поняла она - удивительно верно. В первые же дни она ощутила себя камушком, точно вставленным в изгиб узора огромного мозаичного панно, кусочком смальты, которые подбирает рука Того, кто задумал весь узо.

Ziama poczuła, że znalazła się tam, gdzie jest jej miejsce.

Przywiązanie do ziemi przybiera też w powieści formę radykalnego syjonizmu, choć poglądy te Rubina traktuje tu marginalnie.

\footnotetext{
${ }^{8}$ Zob. И. Мяновска, Дина Рубина вчера и сегодня, Toruń 2003, s. 139-140.

${ }^{9}$ W skład trylogii wchodzą następujące powieści: Почерк Леонардо (2008), Белая голубка Кордовы (2009), Синдром Петрушки (2010).

10 H. Waszkielewicz, Powietrzna trylogia Diny Rubiny, w: D. Oboleńska, U. Patocka-Sigłowy, K. Arciszewska, K. Rutecka (red.), Rosja w krysztale. Rozważania, fakty i miraże, Gdańsk 2014, s. 200.
} 
Bohater o imieniu Uri Bar-Hanina, urodzony jako Jurij Baranow, uczestnik ruchów syjonistycznych jeszcze w Związku Sowieckim, głosi, że naród żydowski powinien żyć na świętej ziemi swoich przodków i zgodnie z zapisem w Księdze Ksiąg wskazywać innym narodom drogę do przyszłości. Ruch syjonistyczny może też przybierać postać, jak w koncepcji innego bohatera - Bori Kagana, który ideę syjonizmu trywialnie i poniekąd pragmatycznie sprowadza do załatwiania własnych „brudnych spraw” na swoim terenie, bez mieszania w nie innych narodów.

Spośród wszystkich postaci Oto idzie Mesjasz! jedynie pisarkę $\mathrm{N}$ - moskwiankę w trzecim pokoleniu - Rubina obdarza wątpliwościami co do słuszności decyzji o wyjeździe z Rosji. Przypisuje jej poczucie bezradności i bezdomności, a także paraliżującą świadomość, że samo pochodzenie na zawsze skazuje ją na życie wśród szczęku broni, a wracać nie ma dokąd, co więcej - wracać nie wolno.

Rubina przedstawia w powieści kolejne etapy drogi rosyjskich Żydów do Izraela. We wspomnieniach Ziamy ożywa Moskwa przełomu lat 80. i 90., i rozwieszane na murach przez jakąśs „patriotyczną” organizację ulotki z wyobrażeniem diabła w postaci żydowskiego chłopca w tradycyjnym stroju oraz żydowską - w rozumieniu zionącego nienawiścią autora wizerunku - fizjonomią: przymrużone oczy, haczykowaty nos i ścięty podbródek (klasyka stereotypowego portretu Żyda rodem z plakatów rozprzestrzenianych przez antysemicką propagandę nazistowskich Niemiec ${ }^{11}$ ).

I kolejny etap drogi. Opowieść pisarki $\mathrm{N}$ o trudach wyjazdu - od Szeriemietiewa, gdzie masowo pozostawiano nadbagaż (dopuszczano zaledwie $40 \mathrm{~kg}$ na osobę), poprzez trudy przesiadkowego pobytu w Budapeszcie i uciążliwe, przeciągające się procedury formalne, po przepełnione w latach 90. repatriantami lotnisko Ben Guriona. Łańcuch fizycznych i psychicznych niedogodności zamyka, witająca rodzinę pisarki $\mathrm{N}$ w Izraelu, rozentu-

11 Zob. M. Michalska-Suchanek, Legenda o Wiecznym Żydzie Tułaczu jako narzędzie nazistowskiej propagandy (na przykładzie filmu „Wieczny Żyd” Fritza Hipplera), w: tejże, O. Gogolin (red.), Z problematyki kultur. Studium interdyscyplinarne, numer monograficzny „World Journal of Theoretical and Applied Sciences" 2016, nr 5, s. 60. 
zjazmowana znajoma syjonistka: „главное, вы - дома! остальное приложится".

Początki swojego pobytu w Izraelu Rubina nazywa „тяжелой болезнью - брюшным тифом, холерой, с жаром, бредом да не дома, на своей постели, а в теплушке бешеного поезда, мчащегося черт знает куда!"12. Repatrianci wpadali z sowieckiej rzeczywistości w daleki od stabilności, niezrozumiały byt Izraela.

Bohaterami powieści Oto idzie Mesjasz! są - jak już wspomniano - repatrianci z początku lat 90., przedstawiciele inteligencji: dziennikarze, pisarze, aktorzy, lekarze. Opis ich trudnych początków w Izraelu Rubina pomieszcza w retrospekcjach, między innymi wspomina próby zarobienia na życie niskopłatną pracą fizyczną (sama przyznaje, że zaczynała od zarabiania sprzątaniem). Powieściowa teraźniejszość natomiast to już nie raczkowanie bohaterów w nowym świecie, lecz zaawansowany etap procesu odnajdowania się w odzyskanej ojczyźnie. Bohaterowie powieści, niegotowi jeszcze do pełnej asymilacji, zbudowali enklawę, do której przenieśli swoje zwyczaje, przyzwyczajenia kulinarne, dobre i złe nawyki (nawet takie jak skłonność do kradzieży klamek i żarówek w Duchowym Centrum Rosyjskiej Diaspory). Utworzyli rosyjskie instytucje kulturalne, na przykład biblioteki, zaczęli wydawać gazety i czasopisma oraz prowadzić rozgłośnię radiową, zapraszali z Rosji osobistości ze świata kultury i nauki. Wspólna historia i los określają wspólnotę, a pamięć o przeszłości stanowi ważny budulec tożsamości i spójności grupy. Bohaterowie powieści dorastali w tym samym świecie, uczyli się w tych samych szkołach, studiowali na tych samych uczelniach, wyrośli z tej samej tradycji kulturowej, cechują ich wspólne mentalność, idiolekt i bagaż doświadczeń (powieść wypełniają liczne odwołania do rosyjskich realiów).

Rubina nie idealizuje Izraela, nie idealizuje też swoich bohaterów. Ich codzienne życie, pełne napięć i codziennych kłopotów, relacjonuje z pobłażliwym (dobrotliwym) dystansem, w tonie ironiczno-satyrycznym, miejscami z wyraźną domieszką groteski. Wypunk-

\footnotetext{
${ }^{12}$ Д. Рубина, Во вратах Твоих, w: tејże, Один интеллигент уселся на дороге, Санкт-Петербург 2001, s. 172-261. Суt za: И. Мяновска, Дина Рубина вчера и сегодня..., s. 35 .
} 
towuje różnice mentalnościowe między nimi a społeczeństwem Izraela, wplatając w narrację ilustrujące je komiczne sytuacje. Obnaża też ignorancję nowoprzybyłych. Wielu $\mathrm{z}$ nich nie zna ani historii, ani kultury, ani religii własnego narodu ${ }^{13}$. Przytoczmy taki oto dialog:

- Ты Танька, среди религиозных людей живешь и ни хрена не знаешь. Хоть бы книжек каких почитала, что ли... Завтра Иом Кипур, ясно тебе? Положено об отпущении грехов молить. И трепетать. - А че мне трепетать? - удивилась Танька. - У меня грехов нет.

Świat pokazany w powieści podzielony jest na „my” i „oni”. Rzeczywistość przedstawiana jest z punktu widzenia nowoprzybyłych rosyjskich Żydów, zatem „oni” — to pozostała społeczność Izraela, niejednorodna pod względem kultury, mentalności, obyczajów, stylu życia — jednocześnie jednak spójna. Rubina mówi o „lękliwej nieprzyjaźni” Izraelczyków do nowej rosyjskiej repatriacji: „Жили тут, не тужили, воевали себе спокойненько, нарабатывали героическую историю страны. Тут вваливаются эти. С шипящими...” (jest to nawiązanie do brzmienia języka hebrajskiego w wykonaniu rosyjskich Żydów). Dla Izraelczyków pozostają „t y m i Rosjanami”. „Oni” - to również uczestnicy poprzednich alii z Europy wschodniej i środkowej, którzy budowali Izrael, wydzierając go bagnu i wrogom. Konflikt ten Rubina oddaje w kilku celnych scenach. Oto do rosyjskojęzycznej rozgłośni radiowej podczas nadawania audycji, poświęconej problemom nowej repatriacji, dzwoni słuchacz: „Я хочу, чтоб эти бляди замолчали навсегда! [...] Мы здесь холодали и голодали, мы воевали и ничего не требовали! А эти бляди советские, чтоб они сдохли, вчера приехали, и тут же подай им, понимаешь, все права и хер на блюде!”. Podobny sens, który sprowadzić można do frazy: my cierpie-

13 To poważny problem tej fali imigracji. Do Izraela przyjeżdżali Żydzi zeświecczeni, często potomkowie związków mieszanych, którzy nie mieli wyraźnej żydowskiej tożsamości, nie znali ani kultury i religii żydowskiej, ani języka hebrajskiego. Wiele było wśród nich osób, które po prostu chciały opuścić ZSRR. Zob. Portal Wirtualny Sztetl, http://www.sztetl.org.pl/pl/ term/404,emigracja-z-zsrr-do-izraela/ (20.02.2017). 
liśmy, a oni przyjeżdżają na gotowe i jeszcze wysuwają roszczenia, zawiera passus dotyczący nowoprzybyłych emerytów, weteranów Wojny Ojczyźnianej. Oprowadzający ich po Jerozolimie Agrippa, sprowokowany druzgoczącą niewiedzą „nowych Izraelczyków” o żydowskiej historii i religii, zarzuca im, że przyjeżdżają, aby żyć na koszt państwa, które opłaca im byt i rozrywki. Czuje złość na nich za wszystkie wojny Izraela, w których nie uczestniczyli, za to, że nie przyjechali, gdy byli potrzebni - ani w roku 1948, ani w latach 60., ani w 1973 (wojna Jom Kippur).

Rubina odnotowuje jednak nie tylko potknięcia, ale i postępy swoich bohaterów $\mathrm{w}$ trudnym procesie asymilacji. Ziama bezwzględnie przestrzega zasady oddzielania noża mlecznego od mięsnego, choć jest to jej jedyny przejaw respektowania koszerności, a Jurik Baranow - jak czytamy — „rasowy przedstawiciel rosyjskiej nacji" - przechodzi giyur (konwersję na judaizm) u ultraortodoksyjnego rabina w Mea Shearim, zamieniając się w Uri Bar-Hanina. Bohaterowie zaczynają obchodzić święta religijne, jak radosne Simchat Tora, kończące roczny cykl czytania w synagodze Pięcioksięgu Mojżeszowego, czy Jom Kippur, któremu zresztą Rubina wyznacza rolę ideowego spoiwa powieści. Niektórzy dopełniają też wymaganych religijnych obrządków. W przededniu Jom Kippur Rabinowicz dokonuje oczyszczającej kąpieli w mykwie, a w świąteczny poranek wraz z mężem pisarki $\mathrm{N}$ i Urim w należnym stroju (w kipach i tałesach) udaje się do synagogi, gdzie przy wtórze śpiewu kantora „zapamiętale kołysze się w modlitwie”, kajając za grzechy. Pisarka N natomiast, mimo wrogiego stosunku do komunistycznych ideałów kibucowych, wyjeżdża z rodziną do kibucu, aby wzorem Izraelczyków przez kilka dni rozkoszować się wiejską przyrodą. Niektórzy nawet nabierają złych przyzwyczajeń, jak lekceważący stosunek do Żydów przybyłych spoza Europy, zwłaszcza z Afryki: „Башковитый. Хоть и Марокашка...” - odnotowujemy w powieści. W bohaterach zaczyna się też odzywać, odwiecznie przypisywany Żydom, zmysł do interesów. Handlują czym się da, nawet ziemią z Góry Oliwnej, którą jeden z bohaterów sprzedaje rosyjskim monasterom i cerkwiom po pięć dolarów za szklankę. W Nazerecie zaś uruchamiają produkcję wizerunków Matki Bo- 
skiej (zatrudniając Arabów i rosyjskich Żydów), a przewodnik Agrippa Sokołow przekonuje pielgrzymów, że jeśli kupować obrazki przedstawiające Najświętszą Maryję, to tylko w miejscu Zwiastowania. Wreszcie organizują sprzedaż na wielką skalę cudownego preparatu na młodość i urodę pod wymowną nazwą „Gruppenkaif” („Группенкайф”).

Sytuację w Izraelu Żydów-repatriantów Rubina z właściwą sobie ironią oddaje w scenie ślubu dwojga Żydów z Ukrainy („хорошая дивчина выходила замуж за хорошего хлопца"). Mamy tu pełną mieszankę elementów rosyjsko-żydowskich: goście zaangażowani w projekt Gruppenkaif, prowadzą slangowe rozmowy o sieci sprzedaży „wyjątkowego" produktu, a także o konieczności utworzenia własnej partii, która uzyskałaby mandaty w Knesecie i w ten sposób wzmocniłaby pozycję „dyskryminowanej rosyjskiej wspólnoty”; wybrzmiewają na przemian piosenki izraelskie i rosyjskie, przy tym większość tych drugich, dawno doczekała się wersji hebrajskiej, a ich rosyjskie pochodzenie się zatarło; ślubu pod chupą udziela rabin $\mathrm{w}$ towarzystwie trzech innych ultraortodoksów przy akompaniamencie niestosownych w tej ceremonii okrzyków "gorzko". Zaślubiny dzięki specjalnemu podnośnikowi odbywają się „między podłogą i sufitem” - jak czytamy w powieści - „między synagogą i kosmodromem Bajkonur". Takie właśnie miejsce, gdzieś między izraelską teraźniejszością i rosyjską przeszłością, Rubina wyznacza własnemu pokoleniu repatriantów.

Nić wiążąca z przeszłością staje się jednak coraz cieńsza. Witia, świat swojej starej ciotki, która lepiej pamięta czasy Stalina (szczególnie te, kiedy sadzano za „перегибы на местах”) niż swoje życie w Izraelu, zaczyna postrzegać jako obcy, a sprawy, o których obwieszcza się na ulubionych przez nią rosyjskich kanałach, jako odległe i niezrozumiałe. Bohaterowie zadomawiają się:

[...] сначала изредка, а потом все чаще - прошлое не то что вдруг проваливалось в голубую пустоту, но застывало, окаменевало [...] А с картинки сегодняшнего дня все быстрее скатывалась катышками пленочка, обнажая яркие цвета [...] в самой середке, в самой глубине, в самой сути.

Pełna asymilacja dokona się $\mathrm{w}$ następnym pokoleniu, reprezentowanym w powieści przez syna pisarki $\mathrm{N}$, co zapowiadają dwa na 
pozór nieznaczące, lecz w istocie symptomatyczne, fakty: chłopak służy w izraelskiej armii i wstydzi się „złego hebrajskiego” matki.

Oto idzie Mesjasz! jest panoramą izraelskiej codzienności lat 90. $\mathrm{z}$ wojną $\mathrm{w}$ tle. Powieść zaczyna się od informacji przekazywanej przez rosyjskojęzyczną stację radiową, że w starciu z bojownikami Hezbollahu zginęło pięciu żołnierzy izraelskich, a czterech zostało rannych. Dalej czytamy o zamachu na szosie z Tel Awiwu do Jerozolimy, podczas którego terrorysta obezwładnił kierowcę i wypełniony po brzegi pasażerami autobus skierował w przepaść, a także o akcjach policji, błyskawicznie reagującej na pozostawiane bez nadzoru podejrzane bagaże, przy stoickim spokoju obserwujących zdarzenie ludzi. Rubina rysuje obraz regionu napięć politycznych i religijnych, których cechą szczególną jest to, że wylecieć w powietrze można kiedykolwiek i gdziekolwiek - na przystanku autobusowym, na targowisku, na plaży, w samochodzie... Pisarka pokazuje izraelską powszedniość lat 90 . — żołnierzy (i żołnierki) na ulicach Tel Awiwu z uzi na ramieniu, coroczne szkolenia wojskowe dla rezerwistów, próbne manewry armii i syreny alarmu przeciwlotniczego. Przywołuje też nazwę Sił Obronnych Izraela — CaHaL i Brygady Golani (jednej z elitarnych brygad piechoty armii izraelskiej), którą właśnie przerzucano na granicę z Libanem (po zakończonej w 1985 roku Pierwszej Wojnie Libańskiej starcia w przygranicznej strefie bezpieczeństwa trwały aż do połowy roku 2000).

Wróćmy jednak do bohaterów powieści. Ziama mieszka w baraku, w żydowskiej osadzie położonej na wzgórzu ponad Ramallah, dniem i nocą strzeżonym przez uzbrojonych mieszkańców. Rubina najwyraźniej umieściła swoją bohaterkę w jednej z osad żydowskich na Zachodnim Brzegu Jordanu (w Autonomii Palestyńskiej). Do pracy w Jerozolimie Ziama wybiera się przed świtem, zanim w meczetach rozlegnie się głos muezina wzywającego na pierwszą modlitwę. Drogę powrotną przebywa ochranianym przez armię autobusem lub samochodem zawsze uzbrojonego przyjaciela - Chaima. Przejazd przez wioskę arabską, znaną z ukrywania terrorystów, za każdym razem staje się walką z dławiącym strachem przed śmiercią od kamienia, koktajlu Mołotowa lub kuli. Na 
zakręcie, przy meczecie, pasażerowie samochodu rozpinają pasy i wstrzymują oddech. Pewnego dnia, w tym właśnie miejscu Chaim zostaje postrzelony. W przedstawionym przez Rubinę świecie obowiązuje zasada „krew za krew”. Niemal natychmiast zorganizowana zostaje akcja odwetowa. Uczestniczą w niej wszyscy mężczyźni osady, nawet ci, dla których palenie samochodów i wybijanie okien w arabskim Ramallah jest — jak w przypadku męża Ziamy, poważnego chirurga — równoznaczne z utratą godności. Przynależność do narodu i kraju zobowiązuje, z góry określa wroga i postawę wobec niego. Wyborowi nie podlegają również emocje — nienawiść jest samorodna i nasila się samoistnie, proporcjonalnie do traumatycznych doświadczeń człowieka. Atak na przyjaciela i świadomość Ziamy, że - gdyby jak zwykle tego dnia z nim jechała - z pewnością nie uniknęłaby arabskiej kuli, wywołuje eskalację nienawiści. Bohaterka przyswaja sobie przekleństwo-zaklęcie dziadka: „Я хочу, чтоб они все сдохли [...] все они, со своими женами, детьми и животными! Чтоб мы хоронили их семь месяцев, не разгибая спины!”. I bez znaczenia pozostaje fakt, że stary Żyd wypowiadał te słowa dawno temu i do innego wroga - ich sens oraz ekspresja okazały się ponadczasowe ${ }^{14}$.

„Нас всех когда-нибудь перебьют” - myśl ta często nawiedza Ziamę, a bezsilnej złości towarzyszy lęk, który sprawia, że na metaliczny dźwięk regulatora długości psiej smyczy wzdryga się, przyjmując go za odgłos odbezpieczanej broni, na strzały na Samaryjskich wzgórzach reaguje natomiast atakami paniki. Widok mijanego podczas spaceru w pobliżu własnego domu staruszka w kufiji i długiej galabiji, który pasie stado kóz, rodzi wizję, że oto Arab znienacka wyciąga broń i strzela do niej, w odwecie zaś — jak jest to w zwyczaju — mieszkańcy osady schodzą do arabskiego Ramallah, wybijają okna w domach i niszczą samochody aż do

${ }^{14}$ Interesujące poglądy prezentuje amerykańska filozof Judith Butler, która twierdzi, że żydowskość definiuje się dynamicznie, a nie statycznie, tj. wyłącznie w odniesieniu do ludności nie-żydowskiej; kiedyś w diasporach — do przedstawicieli kraju goszczącego, a obecnie - do ludności arabskiej. Cecha dystynktywna tożsamości żydowskiej i predykat oznaczający tyle, co „bycie Żydem” generuje się w relacji z tym, co odmienne. Zob. J. Butler, Na rozdrożu. Żydowskość i krytyka syjonizmu, przeł. M. Filipczuk, Warszawa 2014, s. 16-17. 
czasu przybycia izraelskiego wojska, a niezadługo po zdarzeniu, w pobliżu zostaje wybudowana osada żydowska upamiętniająca zabitą kobietę. Żartobliwy ton opowieści przysłania dramatyzm sytuacji, niewątpliwie prawdopodobnej. Kwintesencję powszechnego stosunku do społeczności arabskiej wyraża taki oto dialog: „- По моему, он симпатичный, [...] я его все время здесь вижу. - Симпатичный, - согласился Арье. Главное спиной к нему не поворачивайся...”.

Podjęty w powieści temat sporów żydowsko-arabskich o prawa do ziemi na wzgórzach Judei i Samarii staje się pretekstem do postawienia pytania, które nadal nie traci aktualności — co jest ważniejsze: ziemia czy pokój? Rubina odpowiada słowami młodego rabina odmawiającego racji równie młodemu proarabskiemu lewakowi: „[...] если тебе нечего будет пахать, не на чем строить дом для твоих детей и негде хоронить твоих родителей зачем тебе мир?”. Co symptomatyczne, gdy emocje rozmówców kulminują, telewizyjna emisja dyskusji zostaje przerwana reklamą orzeszków w czekoladzie.

Stosunki żydowsko-arabskie są w Izraelu tematem drażliwym, zwłaszcza jeśli podejmuje go nie-Izraelczyk. Rubina problem ten ilustruje nacechowaną komizmem opowieścią o tym, jak to z Rosji przyjeżdżają osobistości i podczas spotkań, choć uprzedzane, aby wspomnianej kwestii nie poruszać, prędzej czy później próbują nawoływać do ogólnej zgody i przyjaźni. Poczynania te skwitowane są w powieści krótko: „не стоит, мол, лезть в чужую синагогу со своим протухшим интернационализмом".

Rubina, relacjonując teraźniejszość bohaterów, osadza ich w kontekście historycznym, rozumianym, z jednej stron, jako okoliczności towarzyszące indywidualnym losom konkretnych jednostek, z drugiej zaś - jako wyimki z dziejów narodu żydowskiego. W powieści wspomina się o dziesiątkach tysięcy pierwszych osadników, którzy ginęli, osuszając malaryjne błota, a także o żydowskich osadach, wyrastających na pustkowiach niemalże z dnia na dzień. W „narodowej izraelskiej powieści” nie mogło zabraknąć nawiązania do shoah. Za sprawą byłego więźnia obozu o nazwisku Kugel, literata piszącego do rosyjskojęzycznej gazety, Rubina wprowadza 
reminiscencje z obozów koncentracyjnych Dachau i Birkenau, z kolei sen Witi przynosi wspomnienie o obozie w Auschwitz, gdzie w krematorium poniosła śmierć matka bohatera. W przypadku dziadka Ziamy trauma holokaustu ujawniła się natomiast poprzez obdarowywanie wnuczki biżuterią — za kosztowności, jak twierdził, jeśli trzeba, zawsze można się wykupić. W powieści obecny jest również temat odszkodowań rządu niemieckiego dla Żydów, którzy przeżyli shoah. Pieniądze te stają się tragicznym przejawem ironii świata. Sześć milionów Żydów musiało zginąć, aby po pięćdziesięciu latach staruszka dostała od Niemców „śmierdzące marki cuchnącej rekompensaty” („смердящие марки их вонючих компенсаций”), za które Witia z Ziamą wyposażają redakcję w laserową drukarkę.

Rubina nawiązuje wreszcie do czasów bezpośrednio poprzedzających powstanie Państwa Izrael. Przywołuje fakt zaostrzenia się w Palestynie w latach 1946-1948 sytuacji politycznej między Anglikami i organizacjami żydowskimi, co skutkowało ograniczeniem przez władze brytyjskie napływu ludności żydowskiej. Bohater powieści - Chaim, który jako osiemnastoletni łącznik Hagany (żydowskiej organizacji paramilitarnej, działającej w latach 1920-1948 w ówczesnym Mandacie Palestyny) pilotował grupy żydowskich uchodźców, przerzucanych z Europy do Turcji, i dalej do Palestyny, wspomina statki z uchodźcami żydowskimi, którzy przeżyli shoah, aby zginąć u brzegów własnej ziemi (w rzeczywistości, statki niewpuszczane do Palestyny były ostrzeliwane i/lub odholowywane na Cypr, gdzie założono obóz dla internowanych lub z powrotem odpływały do portów Europy Zachodniej ${ }^{15}$ ).

Rubina jest mistrzynią w opisywaniu realiów, wiernie i precyzyjnie odtwarza klimat kulturowy. Tworzone przez nią obrazy są kompletne, choć bez nadmiaru szczegółów. Detale uchwyca celnie i precyzyjnie, rzetelnie oddając charakter opisywanego miejsca. O znaczeniu, jakie Rubina przydaje elementom bytu i kolorytowi miejsca świadczy choćby dołączony do powieści słowniczek najważniejszych pojęć.

${ }^{15}$ Zob. więcej: T. Segev, Siódmy milion. Izrael - piętno zagłady, przeł. B. Gadomska, Warszawa 2012, s. 126-130. 
Wydarzenia powieściowe są dokładnie lokalizowane. Wystarczy prześledzić trasę, jaką Ziama przemierza z Jerozolimy do Tel Awiwu, aby z opisu wyłowić znane nazwy, i oto, co widzimy: autobus krętymi ulicami wyjeżdża z miasta na szosę, wkrótce wysoko z lewej strony i z tyłu widoczna jest oddalająca się Jerozolima, a z prawej w dole wyłaniają się zarysy Ramotu - białego z czerwonymi dachówkami. Z daleka dostrzec można wieżę grobowca proroka Samuela, lecz autobus już zjeżdża z gór w dolinę Ajalon i powoli zbliża się do Tel Awiwu. Na horyzoncie odsłania się charakterystyczny pagórek - wysypisko śmieci z „pełzającymi” po jego grzbiecie ciężarówkami-śmieciarkami, dalej most La Guardia. Wreszcie autobus dojeżdża do nowego telawiwskiego dworca autobusowego, wypełnionego wielokulturowym tłumem.

W powieści odnajdujemy mnóstwo nazw geograficznych. Mowa o roztaczającym się widoku na Bet Jisra’el w Zachodniej Jerozolimie, miastach Nazaret, Hebron i Akko, o naszpikowanej bronią arabską Judei i Samarii (terytorium Autonomii Palestyńskiej), górze Megiddo oraz Pustyni Judejskiej (Judzkiej). Pojawia się również odniesienie do francuskich chasydów Chabad-Lubawicz (ruchu zainicjowanego pod koniec XVIII wieku w rosyjskiej miejscowości Lubawicze, ros. Любавичи); w synagodze wybudowanej na polecenie stojącego na ich czele lubawiczewskiego rabina modlą się bohaterowie powieści.

Rubina „umie czytać miasto”16 - pisze Halina Waszkielewicz. W powieści wiernie oddaje topografię Jerozolimy i Tel Awiwu. Wspomina dzielnice Jerozolimy, np. ultraortodoksyjną Mea Shearim, której mieszkańcy wciąż posługują się jidysz, gdyż mówienie po hebrajsku traktują jako bezczeszczenie świętego języka, czy też starą dzielnicę Musrara, gdzie w kurdyjskiej restauracji ginie Ziama. Wymienia nazwy najważniejszych miejsc trzech stykających się w Jerozolimie religii: Bazyliki Grobu Świętego, Ściany Zachodniej Drugiej Świątyni Jerozolimskiej (Ściana Płaczu) i Meczetu Omara, a także Góry Oliwnej, Bramy Złotej oraz synagogi wielkiego kabalisty Icchaka Lurii (synagoga Ari), z widokiem na pokrytą lasem górę Meron. Razem z Ziamą przemierzamy ulicę Jaffo, prowadzącą

${ }^{16}$ H. Waszkielewicz, Powietrzna trylogia Diny Rubiny..., s. 196. 
do jerozolimskiego bazaru Mahane Yehuda, aby dalej, przeciskając się wąskimi uliczkami między małymi, starymi sklepikami, dotrzeć do ulicy Agripas.

Jerozolima odpowiada kulturowo-etnicznej mieszance izraelskiego społeczeństwa. Ulice powieściowego miasta wypełniają ortodoksi, ultraortodoksi, Żydzi sefardyjscy, przeważnie o bardzo ciemnej skórze, studenci jesziw, chasydzi, Ormianie, i cała masa „olim” (repatriantów ze wschodniej i środkowej Europy). Pluralistyczny charakter kulturowej rzeczywistości odzwierciedlają kulinaria - marak kubbeh (specjalność irakijskich i kurdyjskich Żydów), arabska shoarma, bliskowschodnia pita, żydowskie burekasy czy niekoszerne wieprzowe steki (u Rubiny specjalność pewnego Urugwajczyka) i oczywiście marynowane w białym winie mięso na szaszłyki w domach rosyjskich Żydów.

Końcową część powieści wypełnia święto Jom Kippur, inaczej Sądny Dzień lub Dzień Przebłagania - ważne żydowskie święto pojednania i wybaczenia, kończące Dziesięć Dni Pokuty. Księga Kapłańska Starego Testamentu ${ }^{17}$ zapowiada, że Aaron - brat Mojżesza - w Dniu Przebłagania przyprowadzi dwa kozły, jednego przeznaczonego na ofiarę przebłagalną dla Pana, drugiego dla Azazela (demona pustyni): „Kozła wylosowanego dla Azazela postawi żywego przed Panem, aby dokonać na nim przebłagania, a potem wypędzić go dla Azazela na pustynię" ${ }^{\prime 1}$. Do tego fragmentu Księgi Kapłańskiej odwołuje się Rubina, „ogrywając go” w powieści z właściwym sobie humorem. W przeddzień Jom Kippur bohaterowie organizują spotkanie suto zakrapiane alkoholem. Saszka Rabinowicz czyta fragment Księgi Kapłańskiej o tym, jak Aaron kładzie obie ręce na głowę kozła żywego, wyznaje nad nim wszelkie nieprawości Izraelitów, przestępstwa i grzechy, po czym przepędza na pustynię, a ten niesie na sobie wszystkie nieprawości ludu ${ }^{19}$. Pijany bohater, ujrzawszy nagle kozła, skubiącego kwiatki na przydomo-

17 Stary Testament, Księga Kapłańska, http://biblia.deon.pl/rozdzial.php?id=87\#W27 (15.02.2017).

18 Tamże, 16:10.

${ }^{19}$ Zob. tamże, 16:21-22. 
wym gazonie, bierze go za owego kozła mitycznego (w rzeczywistości kozioł uciekł pasterzowi i błąkał się po okolicy) i postanawia, że w ostatnim dniu pokutnym złoży na niego wszystkie grzechy. We dwóch, z nie mniej pijanym Doktorem, próbują zwierzę pojmać, ale przestraszony kozioł wyrywa się i ucieka w dół po stromym zboczu, ciągnąc za sobą Doktora.

Księga Kapłańska mówi jednak i o drugim koźle:

Potem Aaron przyprowadzi kozła, wylosowanego dla Pana, i złoży go na ofiarę przebłagalną [...] zabije kozła jako ofiarę przebłagalną za lud [...] dokona przebłagania nad Miejscem Świętym za nieczystości Izraelitów i za ich przestępstwa według wszystkich ich grzechów [...] dokona przebłagania za siebie samego, za swój dom i za całe zgromadzenie Izraela ${ }^{20}$.

Funkcję przebłagalnego rytu złożenia kozła dla Żydowskiego Boga podczas Sądnego Dnia ${ }^{21}$ spełnia śmierć Ziamy. Jednocześnie jest to ziszczenie się idei pisarki N — bohaterka jej nowej powieści, jak Ziama kochająca swoją ziemię („единственное для нее пространство”) i zamieszkujący ją naród, oddaje życie w ofierze „za naród, za grzechy jego, za życie jego, za ziemię”, i śmierć ta przynosi odkupienie. Zwieńczeniem powieści Oto idzie Mesjasz! są słowa, które wcześniej, w święto Jom Kippur, wybrzmiewają z ust Rabinowicza: „Это замена моя, это подмена моя, это искупление мое”. Nie bez znaczenia jest tu fakt, że pisarka N przybywa niegdyś do Izraela dokładnie w przeddzień święta Jom Kippur, a losy „jej bohaterki”, która istniała dotąd tylko w zamyśle, dopisuje samo życie, w którymś z kolejnych Świąt Przebłagania.

Rubina pokazuje śmierć Ziamy jako konsekwencję absurdalnego splotu wydarzeń. Bohaterka ginie, celebrując w restauracji zakończenie Jom Kippur, z rąk takiego jak ona repatrianta z Rosji, żołnierza, syna pisarki N (w ten sposób pisarka N zostaje bezpośrednio wciągnięta $\mathrm{w}, \mathrm{W}$ ofiarniczy akt przebłagalny”, stanowiący tragiczne

\footnotetext{
${ }^{20}$ Zob. tamże, 16:9,15-17.

${ }^{21}$ Zob. S. Jędrzejewski, Jom Kippur - próba znalezienia genezy, „SEMINARE” 2008, nr 25, s. 95-110, http://cejsh.icm.edu.pl/cejsh/element/bwmeta1.element. desklight-19a11322-5c98-4d60-906b-cae30cf54719/c/tom25-08-jedrzejewski. pdf (1.02.2017).
} 
powielenie losu wymyślonej przez siebie postaci). Żołnierz strzela do młodej Arabki, która właśnie zamierza ugodzić Ziamę nożem. Ta jednak, w ofiarnym akcie, własnym ciałem zasłania swoją niedoszłą oprawczynię. I kolejna ironia losu - syn pisarki N tylko przez przypadek pojawia się w restauracji pod bronią: nie ma pieniędzy na transport, a pełne umundurowanie umożliwia darmowy przejazd. Napastniczka natomiast nie należy do żadnej organizacji terrorystycznej, lecz jest zdesperowaną młodą kobietą, która zaszła w ciążę i boi się śmierci z rąk braci jako kary za zhańbienie rodziny. Szanse na przeżycie widzi w zabiciu jakiegoś Żyda, aby w ten sposób schronić się w więzieniu; dziecko po porodzie odda, a zabójstwo wroga w oczach bliskich przyniesie jej chwałę. Ziama umiera u schyłku święta głoszącego pojednanie, przy wtórze nienawiści płynącym z wypełnionej Żydami restauracyjnej sali („длящийся бесконечно крик ненависти”). Jako prawdziwa córa Syjonu dopływa przez oczyszczające źródlane wody Jeruszalaim do miejsca, gdzie czeka na nią nieżyjący dziadek, jej Mesjasz. Kobieta wraca do korzeni. Śmierć (taka śmierć!) sankcjonuje jej przynależność do żydowskiej tradycji, kultury i religii. „Теперь и я - Ершолойм” - myśli.

Pierwszą część powieści rozpoczyna epigraf o powtórnym przyjściu Mesjasza zaczerpnięty z Trzynastu zasad wiary największego średniowiecznego talmudysty Majmonidesa: „Я верую полной верой в приход Мессии, и хотя он медлит, я буду ждать каждый день, что он придет”. Ziama swojego Mesjasza już się doczekała.

Rekapitulując, ma rację Szafrańska, nazywając Oto idzie Mesjasz! narodową powieścią izraelską. Rubina uchwyciła ten moment w życiu Żydów - repatriantów z Rosji, gdy już w pełni odnaleźli się w odzyskanej ojczyźnie i wchodzą na drogę asymilacji z izraelską społecznością. Powiedzmy wyraźnie, postaci powieści nie szukają własnej tożsamości. Chociaż często niezdarnie poruszają się w świecie żydowskich tradycji i popełniają masę niezręczności, doskonale wiedzą, kim są i gdzie jest ich miejsce. Rubina pokazuje wrastanie swoich bohaterów - z jednej strony - w żydowską kulturę i religię, z drugiej - w niespokojną izraelską codzienność. To przypieczętowanie żydowskiej tożsamości przedstawione jest 
na tle Izraela lat 90. Rubina nie stosuje przy tym rozbudowanych opisów, tylko oszczędnie wskazuje charakterystyczne elementy, które w świadomym czytelniczym odbiorze (tj. podbudowanym rudymentarną wiedzą na temat kultury i religii żydowskiej, a także historii oraz teraźniejszości Izraela) rozwijają się w pełny i spójny obraz.

Мирослава Михальска-Суханек

Резюме

«МЕЖДУ СИНАГОГОЙ И КОСМОДРОМОМ БАЙКОНУР». О РОМАНЕ ДИНЫ РУБИНОЙ ВОТ ИДЕТ МЕССИЯ!

На непредсказуемую, сложную повседневность «российского Израиля» 90-х годов Рубина смотрит с точки зрения еврейской традиции, культуры и религии. Создает образ, насыщенный в равной степени комизмом, иронией, а даже гротеском, что рефлексией философско-религиозного характера. Роман развивает мысль о предназначении еврейского народа и единстве евреев с собственной землей. Персонажи романа не ищут собственной идентичности, прекрасно знают, кто они, и где их место. А все это на фоне картины региона политических и межконфессиональных напряжений и реалий (в том числе географических и топографических) Израиля, а также верно воссозданного его культурного климата.

Mirosława Michalska-Suchanek

Summary

"BETWEEN THE SYNAGOGUE AND THE BAIKONUR COSMODROME". ABOUT THE NOVEL BY DINA RUBINA HERE COMES THE MESSIAH!

Rubina looks at the unpredictable and difficult every-day reality of "Russian Israel" in the 90s from the perspective of Jewish tradition, culture and religion. She creates an image full of equal amounts of both comedy, irony and even grotesque and philosophical and religious thoughts. The novel develops the idea of the destiny of the Jewish people and the unity of Jews with their own land. The novel's characters are not looking for their own identity - they know very well who they are and where they belong. The background of the novel are descriptions of the regional political and religious conflicts as well as realities (including geographical and topographical) of Israel and faithfully reproduced cultural climate. 